\title{
Malondialdehyde and anion patterns in exhaled breath condensate among subway workers
}

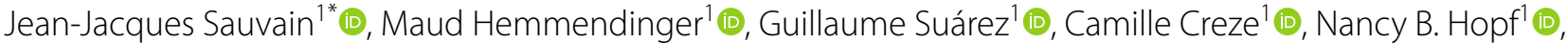

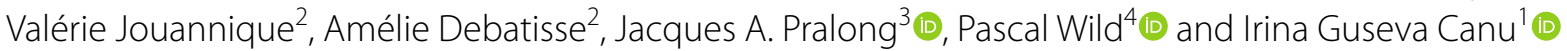

\begin{abstract}
Background: Underground transportation systems can contribute to the daily particulates and metal exposures for both commuter and subway workers. The redox and metabolic changes in workers exposed to such metal-rich particles have yet to be characterized. We hypothesize that the distribution of nitrosative/oxidative stress and related metabolic biomarkers in exhaled breath condensate (EBC) are modified depending on exposures.

Results: Particulate number and size as well as mass concentration and airborne metal content were measured in three groups of nine subway workers (station agents, locomotive operators and security guards). In parallel, pre- and post-shift EBC was collected daily during two consecutive working weeks. In this biological matrix, malondialdehyde, lactate, acetate, propionate, butyrate, formate, pyruvate, the sum of nitrite and nitrate $\left(\Sigma \mathrm{NO}_{x}\right)$ and the ratio nitrite/ nitrate as well as metals and nanoparticle concentrations was determined. Weekly evolution of the log-transformed selected biomarkers as well as their association with exposure variables was investigated using linear mixed effects models with the participant ID as random effect. The professional activity had a strong influence on the pattern of anions and malondialdehyde in EBC. The daily number concentration and the lung deposited surface area of ultrafine particles was consistently and mainly associated with nitrogen oxides variations during the work-shift, with an inhibitory effect on the $\Sigma \mathrm{NO}_{\mathrm{x}}$. We observed that the particulate matter (PM) mass was associated with a decreasing level of acetate, lactate and $\Sigma \mathrm{NO}_{x}$ during the work-shift, suggestive of a build-up of these anions during the previous night in response to exposures from the previous day. Lactate was moderately and positively associated with some metals and with the sub-micrometer particle concentration in EBC.
\end{abstract}

Conclusions: These results are exploratory but suggest that exposure to subway PM could affect concentrations of nitrogen oxides as well as acetate and lactate in EBC of subway workers. The effect is modulated by the particle size and can correspond to the body's cellular responses under oxidative stress to maintain the redox and/or metabolic homeostasis.

Keywords: Exhaled breath condensate, Underground, Particulate matter, Exposure, Anion, Metabolism

\footnotetext{
${ }^{*}$ Correspondence: jean-jacques.sauvain@unisante.ch

${ }^{1}$ Department of Occupational and Environmental Health, Center

for Primary Care and Public Health (Unisanté), University Lausanne, Route de la Corniche 2, 1066 Epalinges, Switzerland

Full list of author information is available at the end of the article
}

\section{Background}

Exposure to ambient particulate matter (PM) is associated with the development and exacerbation of different respiratory and cardiovascular diseases $[1,2]$. New evidences suggest that exposure to such pollutants is also able to induce more systemic effects beyond the cardiopulmonary system, e.g. favoring the progress of give appropriate credit to the original author(s) and the source, provide a link to the Creative Commons licence, and indicate if changes were made. The images or other third party material in this article are included in the article's Creative Commons licence, unless indicated otherwise in a credit line to the material. If material is not included in the article's Creative Commons licence and your intended use is not permitted by statutory regulation or exceeds the permitted use, you will need to obtain permission directly from the copyright holder. To view a copy of this licence, visit http://creativecommons.org/licenses/by/4.0/. The Creative Commons Public Domain Dedication waiver (http://creativecommons.org/publicdomain/zero/1.0/) applies to the data made available in this article, unless otherwise stated in a credit line to the data. 
metabolic diseases like type 2 diabetes or obesity [3]. The full mechanistic understanding of the development for such pathologies is lacking but increasing data suggest that oxidative stress and inflammation are central in explaining these effects. A plausible hypothesis is that the oxidative stress induced by ambient PM exposure modifies the cellular redox homeostasis, resulting in antioxidant depletion, lipid peroxidation and mitochondrial dysfunction $[4,5]$. In order to repair and restore the cellular functional processes, a reprogramming of the energy metabolism will occur [6]. Indeed, multiple metabolic pathways have been observed to be modified either in in vitro $[7,8]$ or in in vivo models [9] after exposure to ambient PM. In these studies, the affected metabolic pathways were related to the metabolism of glucose [10, 11], the tricarboxylic acid cycle as well as glutathione, arginine, proline, nitrogen and lipids metabolism [6]. Due to such multiple and complex inter-relations, a panel of metabolites (and not solely one molecule) should be considered when characterizing and discriminating a pathological state resulting from PM exposure [12].

The pathogenicity from PM exposure has been linked, at least, to their size and chemical composition; particles with smaller aerodynamic diameters are more prone to penetrate deeper into the lung and induce a greater biological activity in sensitive regions such as the alveoli [13]. Ultrafine particles (UFP) (mean aerodynamic diameter $<100 \mathrm{~nm}$ ) have a high deposition in all regions of the respiratory tract [14]. Beside their chemical variability, related to their sources, ambient PM might also have adsorbing properties for organic compounds or metals, playing the role of a carrier of noxious components to vulnerable regions of the lungs [13]. In order to understand the effect of specific chemicals, it is important to consider model particles enriched with some chemicals. In this frame, underground railways are of special interest as their PM concentration and composition differ strongly from ambient PM [15]. Indeed, PM encountered in subways contain mainly metallic elements, originating from specific processes such as wheel and brake wear or electric arcs. Exposure to PM during subway commuting in different Canadian cities has been reported to contribute to the majority of the personal daily exposure to metals and to $10-20 \%$ of the total $\mathrm{PM}_{2.5}$ exposure [16]. A similar observation was reported for Milan city, where the contribution of the subway PM on the total mass deposited in the lung was quite important during the winter season [17]. Some of these elements, such as iron, copper, and manganese, might have different oxidation states depending on the biological conditions and be redox-active. Indeed, subway PM possess intrinsic oxidative potential but of variable intensity and mainly associated to copper or nickel but not iron $[18,19]$. The possible presence of mixed redox state of metals in these particles, as reported for iron [20] can promote Fenton-like reactions, which induce oxidative damage to biological constituents [21]. Therefore, exposure to subway PM can affect the cell metabolism and particularly, in the mitochondria. Karlsson et al. [22] reported the mitochondria depolarization of human lung epithelial cells A549 to be induced by such PM, suggesting a perturbation in energy storage during the oxidative phosphorylation.

The lung is the main entry portal of PM and by consequence, the place where redox homeostasis perturbations is observed first. It is thus interesting to gain information relative to inflammation or oxidative stress status from this organ. For that purpose, exhaled breath condensate $(E B C)$ is a relevant biological matrix as it is collected non-invasively [23] and allows measuring different biomarkers of exposure and effect [24]. EBC is also proposed as a biological matrix of choice for metabolomics studies [25]. We recently validated a simple method to measure various anions related to metabolism (lactate, acetate, formate, propionate, butyrate, pyruvate) and nitrosative stress (nitrite, nitrate) in EBC [26]. The application of this method to EBC samples collected from workers exposed to soapstone and quartz suggested a modification of the distribution of some of these anions, particularly for quartz exposed workers [26].

In order to evaluate to which extent exposure to subway PM induces metabolic changes in human respiratory system, we made the hypotheses that these particles may have effects on nitrosative/oxidative stress biomarkers (nitrite, nitrate, malondialdehyde) and/or on different metabolism biomarkers (acetate, lactate, formate) measured in the EBC. Our aim was to check these hypotheses based on a longitudinal pilot-study among subway workers followed up during a period of two consecutive weeks, whose exposure was well characterized [27, 28].

\section{Results \\ Anion, MDA, metals and sub-micrometer particle concentrations in $\mathrm{EBC}$}

A total of nine workers were enrolled in this pilot study as described in the registered protocol [29]. Three different professional groups were included: station agents, locomotive operators and security guards. Their personal daily exposure to $\mathrm{PM}_{10}, \mathrm{PM}_{4}, \mathrm{PM}_{2.5}$ and ultrafine fraction as well as their metal content was measured for two consecutive working weeks. In parallel, EBC samples were collected daily pre- and post-shift. Exposure concentrations are described in detail elsewhere [27, 28] and are summarized in Additional file 1: Table S1. Figure 1 (and Additional file 1: Table S2) illustrates the EBC anion concentrations for the three professional groups, averaged across the day of the week and work-shift. The 


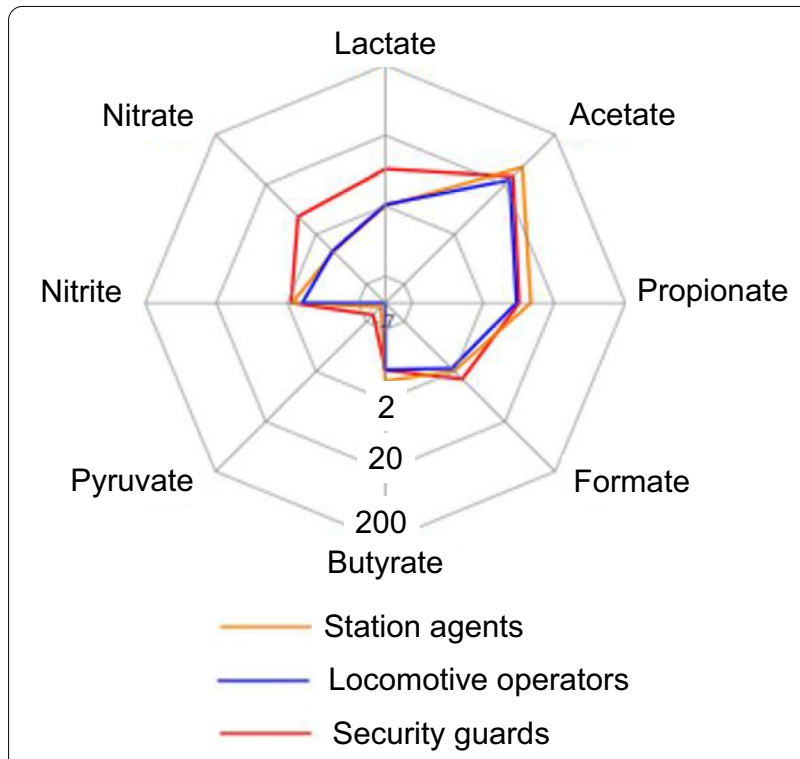

Fig. 1 Mean concentrations of the anions $[\mu M]$ in the $E B C$ of the three professional groups across the day of the week and work-shift

inter-subject variance for the different anions, corresponding to the variance observed during the ten working days, was comprised between 2 and $34 \%$ of the total variance. Acetate, propionate and butyrate, corresponding to short chain fatty acids (SCFA), were strongly correlated, with Pearson correlation coefficients comprised between 0.69 and 0.88 ( $p$-values $<0.0001$ for all correlations), suggesting a similar source (data not shown). The mass proportion of each SCFA anion to their sum was similar for the three professional groups with mean values for acetate/propionate/butyrate of $8 / 2 / 0.2$ respectively. This distribution is quite different from the typical 3:1:1 ratio observed from microbial fermentation [30]. We noted a moderate correlation between nitrite and formate (Pearson $\rho: 0.46, p=0.0001$ ) or nitrite and acetate (Pearson $\rho: 0.56, p=0.0001$ ).
MDA could be measured in all professional groups, and most concentrations fell within the concentration range reported in healthy controls, using the same analytical method [31]. Station agents exhibited the highest MDA concentrations $\left(160 \mathrm{ng} / \mathrm{L}, \mathrm{CI}_{95 \%}=79-240 \mu \mathrm{g} / \mathrm{L}\right.$, Additional file 1: Table S2). Iron was a predominant element in the collected underground particles (up to 40.2\% for $\mathrm{PM}_{10}$, Additional file 1: Table S1), but it could not be consistently quantified in the EBC samples. Only $25 \%$ of these samples presented iron levels above the limit of quantification (LOQ) of $1 \mu \mathrm{g} / \mathrm{L}$ and $59 \%$ had concentration comprised between LOQ and limit of detection (LOD), set at $0.3 \mu \mathrm{g} / \mathrm{L}$. The concentration in descending order of the quantified elements in $\mathrm{EBC}$ was: $\mathrm{Zn}>\mathrm{Cu}>\mathrm{Ni}>\mathrm{Mn}$. $\mathrm{Cu}$ was significantly correlated with $\mathrm{Zn}$ and $\mathrm{Ni}$ for all professional groups. The averaged concentration of sub-micrometer particles in EBC (using nanoparticle tracking analysis-NTA [26]) was relatively low, comprised between 3.5 and $4.3 \times 10^{7}$ particles $/ \mathrm{ml}$, with a mean size distribution between 156 and $174 \mathrm{~nm}$.

\section{Correlations between the EBC variables}

Table 1 presents the Pearson correlation coefficients between the anions and the other variables measured in the $146 \mathrm{EBC}$ samples (MDA, metals and concentration of sub-micrometer particles measured with NTA). Only five variables for anions were considered in this analysis because propionate and butyrate were both strongly correlated with acetate, and pyruvate levels were very low and near the LOD. We observed that lactate was positively and moderately associated with the presence of $\mathrm{Cu}, \mathrm{Cr}, \mathrm{Ni}$ and $\mathrm{Zn}$ as well as with the concentrations of sub-micrometer particles in EBC (NTA). Acetate was negatively correlated with most of the variables, but only statistically significant with $\mathrm{Cu}$ and $\mathrm{Cr}$. A low but statistically significant positive correlation was also observed between acetate and MDA. Formate was positively and strongly associated with MDA and moderately with Zn. A low but statistically significant positive correlation was

Table 1 Correlation* between EBC levels of the different anions with MDA, metals and sub-micrometer particles

\begin{tabular}{|c|c|c|c|c|c|}
\hline & Formate $(\mu \mathrm{mol} / \mathrm{L})$ & Acetate $(\mu \mathrm{mol} / \mathrm{L})$ & Lactate $(\mu \mathrm{mol} / \mathrm{L})$ & $\Sigma \mathrm{NO}_{\mathrm{x}}(\mu \mathrm{mol} / \mathrm{L})$ & $\mathrm{NO}_{2}^{-} / \mathrm{NO}_{3}^{-}$ \\
\hline MDA (ng/L) & $0.53(0.001)$ & $0.29(0.001)$ & $0.12(0.169)$ & $0.06(0.468)$ & $0.29(0.001)$ \\
\hline $\mathrm{Cu}(\mu \mathrm{g} / \mathrm{L})$ & $0.05(0.58)$ & $-0.21(0.019)$ & $0.47(0.001)$ & $0.07(0.431)$ & $-0.23(0.009)$ \\
\hline $\mathrm{Mn}(\mu \mathrm{g} / \mathrm{L})$ & $0.11(0.22)$ & $-0.19(0.033)$ & $0.18(0.048)$ & $0.14(0.107)$ & $-0.14(0.118)$ \\
\hline $\mathrm{Cr}(\mu \mathrm{g} / \mathrm{L})$ & $0.14(0.134)$ & $-0.22(0.018)$ & $0.21(0.022)$ & $0.004(0.970)$ & $-0.15(0.100)$ \\
\hline $\mathrm{Ni}(\mu \mathrm{g} / \mathrm{L})$ & $0.03(0.973)$ & $-0.07(0.463)$ & $0.36(0.001)$ & $0.004(0.968)$ & $-0.13(0.150)$ \\
\hline $\mathrm{Zn}(\mu \mathrm{g} / \mathrm{L})$ & $0.24(0.008)$ & $-0.14(0.128)$ & $0.23(0.010)$ & $0.18(0.046)$ & $-0.18(0.044)$ \\
\hline Number concentration (NTA) $\left(\# / \mathrm{cm}^{3}\right)$ & $-0.01(0.945)$ & $-0.10(0.241)$ & $0.32(0.001)$ & $-0.16(0.083)$ & $0.03(0.765)$ \\
\hline Mean hydrodynamic size (NTA) (nm) & $-0.01(0.903)$ & $-0.03(0.724)$ & $0.19(0.038)$ & $-0.13(0.144)$ & $0.10(0.267)$ \\
\hline
\end{tabular}

* Pearson correlation coefficients, with $p$-value between bracket. Bold values indicate a statistically significant correlation ( $p<0.05)$ 
observed for the ratio $\mathrm{NO}_{2}{ }^{-} / \mathrm{NO}_{3}{ }^{-}$with MDA and negative with $\mathrm{Cu}$ and $\mathrm{Zn}$ (borderline). No association was observed between MDA and metals in EBC or between MDA and EBC's sub-micrometer particles (data not shown).

\section{Dependence of the anion concentration as a function of the professional activity}

Results from modelling the anion concentration as a function of work-shift (averaged levels of selected anions for pre- and post-shift are given in Additional file 1: Table S3), day of the week and working group in the mixed model are given in Fig. 2. Compared to the mean concentrations for locomotive operators and security guards, station agents presented a statistically significant higher level of acetate $(p=0.001)$ and $\mathrm{NO}_{2}{ }^{-} / \mathrm{NO}_{3}{ }^{-}$ratio $(p=0.0001)$ (Fig. 2A and B). For security guards, lactate $(p=0.003)$ and the sum of nitrite and nitrate $\left(\sum \mathrm{NO}_{\mathrm{X}}\right.$, $p=0.0001)$ increased in comparison with station agents and locomotive operators (Fig. $2 \mathrm{C}$ and D). In addition, security guards presented the lowest $\mathrm{NO}_{2}{ }^{-} / \mathrm{NO}_{3}{ }^{-}$ratio and a higher level of lactate and $\Sigma \mathrm{NO}_{\mathrm{X}}$ compared to locomotive operators. We did not observe any clear effect for the day of the week on the anion concentrations, except for the $\mathrm{NO}_{2}{ }^{-} / \mathrm{NO}_{3}{ }^{-}$ratio and the $\Sigma \mathrm{NO}_{\mathrm{X}}$ (Fig. $2 \mathrm{~B}$ and $\mathrm{D}$, right panel). For the $\mathrm{NO}_{2}{ }^{-} / \mathrm{NO}_{3}{ }^{-}$ratio, a statistically significant decreased ratio was observed on Wednesday $(p=0.036)$ compared to Monday, which was considered as the reference. On the contrary, a statistically significant increase for $\Sigma \mathrm{NO}_{\mathrm{X}}$ was determined on Tuesday and Wednesday ( $p=0.013$ and $p=0.022$ respectively) compared to Monday. MDA level in EBC was the highest for the station agent group (Additional file 1: Table S1) and decreased for locomotive operators and security guards (Additional file 1: Fig. S1), but without reaching a statistical significance $(p=0.062)$.

\section{Association between exposure and the anion concentrations in EBC}

A key question was to know whether the change in concentration of anions during a work-shift (the difference between end of shift and before shift) could be due to the PM exposure, either measured the same day (lag 0), one or two days before (lag 1 and lag 2, respectively). The developed statistical model indicated that the concentration of some anions in EBC quickly changed after exposure (lag 0 , Table 2 ). We observed a positive and significant association $(p=0.02)$ between exposure to $\mathrm{PM}_{4}$ and the variation of formate level during the working day. Inhalation of UFP also had a rapid influence on the levels of acetate, $\Sigma \mathrm{NO}_{\mathrm{x}}$ and $\mathrm{NO}_{2}{ }^{-} / \mathrm{NO}_{3}{ }^{-}$. The acetate variation was negatively associated with UFP size $(p=0.01)$ suggesting that the smaller the UFP size, the higher the EBC acetate level at the end of shift. The particle number concentration (PNC) and the lung deposited surface area (LDSA) were also negatively associated with the variation of $\Sigma \mathrm{NO}_{\mathrm{X}}(p=0.01$ and 0.01 , respectively). This suggests an inhibitory effect of the PNC and LDSA during the shift on $\Sigma \mathrm{NO}_{\mathrm{x}}$. Finally, the variation of the $\mathrm{NO}_{2}{ }^{-} / \mathrm{NO}_{3}{ }^{-}$ratio and the PNC were positively associated $(p=0.04)$ for the same day (lag 0). These results indicate that UFP exposure favor the formation of $\mathrm{NO}_{2}{ }^{-}$compared to $\mathrm{NO}_{3}{ }^{-}$.

Delayed effects (at lag 1, Table 3) resulting from exposure to subway PM on the anions concentrations in EBC were also detected. These effects were mainly associated with the PM mass. A higher EBC lactate concentration was observed at pre-shift compared to post-shift $(p=0.01) 24 \mathrm{~h}$ after $\mathrm{PM}_{10}$ exposure. A similar result was obtained for $\mathrm{PM}_{2.5}$ and acetate $(p=0.02)$ and for $\mathrm{PM}_{4}$ and $\Sigma \mathrm{NO}_{\mathrm{x}}(p=0.02)$. Finally, a statistically significant negative association between the UFP size and the variation of the $\mathrm{NO}_{2}{ }^{-} / \mathrm{NO}_{3}{ }^{-}$ratio was observed $24 \mathrm{~h}$ after UFP exposure. Concentrations of MDA in EBC was positively associated with exposure to $\mathrm{PM}_{10}$ encountered the day before $(p=0.05$; lag 1 , Table 3$)$. At lag 2 ( $48 \mathrm{~h}$ after exposure), no relationship between anion and exposure concentrations was observed.

\section{Discussion}

In this pilot study, we observed that three different professional groups exposed to different subway particulate levels and characteristics presented different patterns of anion in their EBC.

\section{Effect of exposure on the oxidative stress markers and anion levels in EBC}

A detailed description of the workers' exposures to UFP, PM and metals is given elsewhere [27, 28]. Additional file 1: Table S1 gives an overview of the main exposure levels. Salient results are that station agents had the lowest $\mathrm{PM}_{2.5}$ or $\mathrm{PM}_{10}$ mass exposure while PNC was the highest among the three groups $\left(20,000 \# / \mathrm{cm}^{3}\right.$, $\left.\mathrm{CI}_{95 \%}=16,000-24,000 \# / \mathrm{cm}^{3}\right)$. Proportionally, their exposure to fine $\mathrm{PM}$ was the highest, with a $\mathrm{PM}_{2.5} / \mathrm{PM}_{10}$ ratio of 0.89 . Locomotive operators presented the highest $\mathrm{PM}_{2.5}$ and $\mathrm{PM}_{10}$ exposures whereas the security guards were the professional group with the largest exposure to the coarse fraction (size range from 2.5 to $10 \mu \mathrm{m}$, contributing to about $55 \%$ of the $\mathrm{PM}_{10}$ mass). Such exposures are similar to the ones measured in different subways in European and Asian metropoles [32]. Exposure differences between the three professional groups were also observed when considering the metal elemental content in the PM. The locomotive operators were exposed to the highest $\mathrm{Fe}, \mathrm{Zn}$ and $\mathrm{Mn}$ concentrations, whereas the 

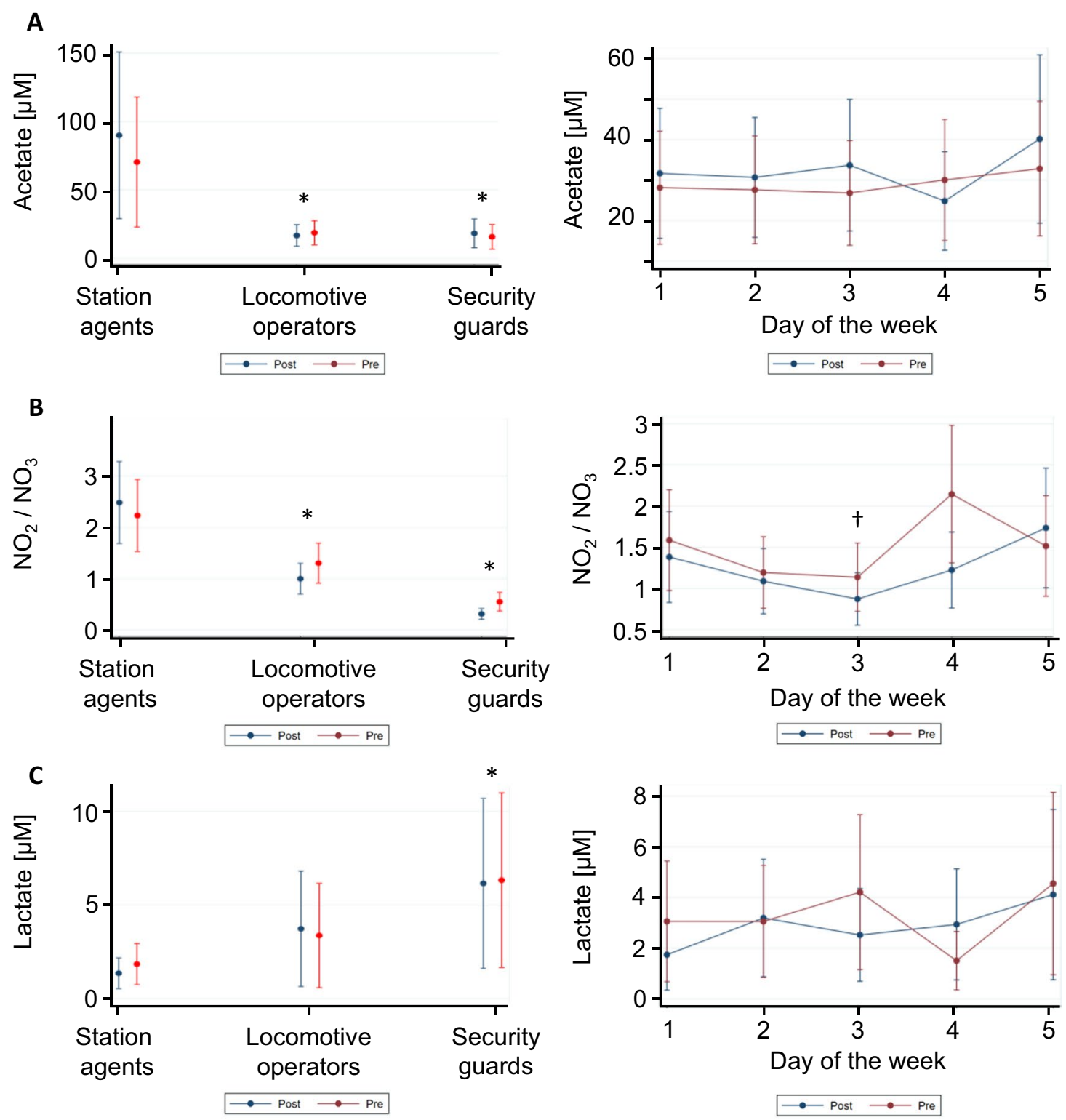

D
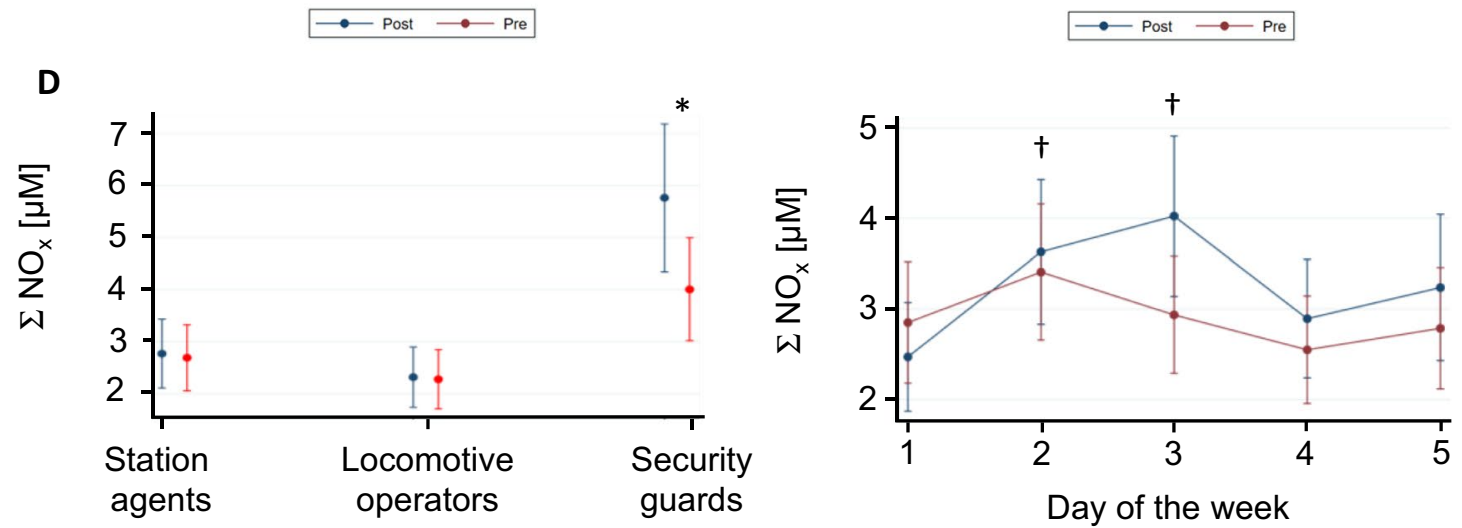

$\longrightarrow$ Post $\longrightarrow$ Pre

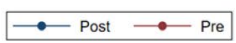

Fig. 2 Effect of the professional activity (left panel) and the day of the week (right panel) on the predicted EBC levels of acetate (A), for the nitrite/ nitrate ratio (B), lactate $(\mathbf{C})$ and $\Sigma \mathrm{NO}_{\mathbf{x}}(\mathbf{D})$, either for pre- or post-shift. ${ }^{*}$ denotes a statistically significant difference $(p<0.05)$ with station agents, considered as reference. + denotes a statistically significant difference $(p<0.05)$ with the first day of the week, considered as reference 
Table 2 Association* between personal exposures and selected anions at lag 0

\begin{tabular}{|c|c|c|c|c|c|c|}
\hline Perso & $\mathrm{MDA}_{\mathrm{e}} / \mathrm{MDA}_{\mathrm{b}}$ & $\begin{array}{l}\text { Formate }_{\mathrm{e}} / \\
\text { Formate }_{\mathrm{b}}\end{array}$ & Lactate $_{\mathrm{e}} /$ Lactate $_{\mathrm{b}}$ & Acetate $_{\mathrm{e}} /$ Acetate $_{\mathrm{b}}$ & $\Sigma \mathrm{NO}_{\mathrm{xe}} / \Sigma \mathrm{NO}_{\mathrm{b}}$ & $\begin{array}{l}\text { Nitrite/Nitrate } / \\
\text { Nitrite/Nitrate }_{\mathrm{b}} \\
\text { Laq } 0^{\text {a }}\end{array}$ \\
\hline & & Lag 0 & Lag 0 & & & \\
\hline $\begin{array}{l}\text { article number } \\
\text { oncentration (\#/ } \\
n^{3} \text { ) }\end{array}$ & 77) & & & & & \\
\hline UFP size (nm) & $68(0.42)$ & $-0.24 \pm 0.25(0.34)$ & 38) & $0.01)$ & $0.33 \pm 0.45(0.47)$ & $(0.31)$ \\
\hline $\begin{array}{l}\text { Lung deposited } \\
\text { surface area }\left(\mu \mathrm{m}^{2} /\right. \\
\left.\mathrm{cm}^{3}\right)\end{array}$ & $.12 \pm 0.25(0.62)$ & $02 \pm 0.09(0.87)$ & $1054(075)$ & $\pm 0.19(0.85)$ & $-0.48 \pm 0.15(0.01)$ & $0.54 \pm 0.27(0.06)$ \\
\hline $\mathrm{PM}_{2.5}\left(\mu \mathrm{g} / \mathrm{m}^{3}\right)$ & $-0.03 \pm 0.20(0.89)$ & $0.05 \pm 0.08(0.54)$ & $-0.04 \pm 0.51(0.93)$ & $-0.02 \pm 0.18(0.93)$ & $0.36 \pm 0.35(0.31)$ & $0.40 \pm 0.28(0.16)$ \\
\hline $\mathrm{PM}_{4}\left(\mu \mathrm{g} / \mathrm{m}^{3}\right)$ & $-0.66 \pm 0.48(0.17)$ & $0.43 \pm 0.18(0.02)$ & $-1.48 \pm 1.04(0.16)$ & $-0.25 \pm 0.37(0.50)$ & $0.36 \pm 0.35(0.31)$ & $-0.16 \pm 0.59(0.78)$ \\
\hline $\mathrm{PM}_{10}\left(\mu \mathrm{g} / \mathrm{m}^{3}\right)$ & $-0.06 \pm 0.23(0.81)$ & $-0.01 \pm 0.09(0.99)$ & $0.22 \pm 0.50(0.65)$ & $0.14 \pm 0.18(0.44)$ & $0.01 \pm 0.17(0.94)$ & $0.14 \pm 0.29(0.63$ \\
\hline
\end{tabular}

* For each pair exposure-anion, the association was evaluated using linear regression with the (log-transformed) daily evolution of anion (ratio post-shift/pre-shift) as dependent variable, the personal exposure as independent predictor variable, and BMI as adjustment variable to control for confounding or effect modification. Bold

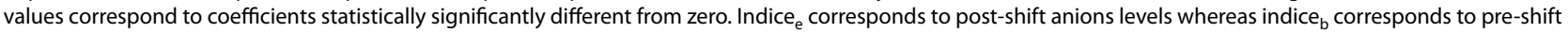
anion levels

Table 3 Association* between personal exposures and selected anions $24 \mathrm{~h}$ after exposure (lag 1)

\begin{tabular}{|c|c|c|c|c|c|c|}
\hline Personal exposure & $\begin{array}{l}M_{\mathrm{e}} / \mathrm{MDA}_{\mathrm{b}} \\
\text { Lag } 1\end{array}$ & $\begin{array}{l}\text { Formate }_{\mathrm{e}} / \\
\text { Formate }_{\mathrm{b}} \\
\text { Lag } 1\end{array}$ & $\begin{array}{l}\text { Lactate }_{\mathrm{e}} / \\
\text { Lactate }_{\mathrm{b}} \\
\text { Lag } 1\end{array}$ & $\begin{array}{l}\text { Acetate }_{\mathrm{e}} / \text { Acetate }_{\mathrm{b}} \\
\text { Lag } 1\end{array}$ & $\begin{array}{l}\sum \mathrm{NO}_{\mathrm{xe}} / \Sigma \mathrm{NO}_{\mathrm{xb}} \\
\text { Lag } 1\end{array}$ & $\begin{array}{l}\text { Nitrit/Nitrat }_{\mathrm{e}} / \text { Nitrit/ } \\
\text { Nitrat }_{\mathrm{b}} \\
\text { Lag } 1\end{array}$ \\
\hline $\begin{array}{l}\text { Particle number } \\
\text { concentration (\#/ } \\
\mathrm{cm}^{3} \text { ) }\end{array}$ & $2 \pm 0.19(0.94)$ & $.03 \pm 0.07(0.60)^{*}$ & $0.06 \pm 0.44(0.89)$ & $0.22 \pm 0.18(0.21)$ & $-0.04 \pm 0.12(0.76)$ & $0.34 \pm 0.27$ \\
\hline UFP size $(\mathrm{nm})$ & $-0.97 \pm 0.74(0.19)$ & $-0.24 \pm 0.24(0.33)$ & $1.93 \pm 1.51(0.20)$ & $-0.94 \pm 0.60(0.12)$ & $0.68 \pm 0.43(0.13)$ & $-2.43 \pm 0.88(0.01)$ \\
\hline $\begin{array}{l}\text { Lung deposited } \\
\text { surface area }\left(\mu \mathrm{m}^{2} /\right. \\
\left.\mathrm{cm}^{3}\right)\end{array}$ & $-0.08 \pm 0.22(0.74)$ & $0.03 \pm 0.08(0.74)^{*}$ & $0.36 \pm 0.52(0.48)$ & $0.18 \pm 0.21(0.39)$ & $0.02 \pm 0.15(0.88)$ & $0.19 \pm 0.32(0.55)$ \\
\hline $\mathrm{PM}_{2.5}\left(\mu \mathrm{g} / \mathrm{m}^{3}\right)$ & $0.46 \pm 0.30(0.13)$ & $0.01 \pm 0.08(0.86)^{*}$ & $-0.45 \pm 0.45(0.33)$ & $-0.43 \pm 0.18$ & $t-0.08 \pm 0.17(0.64)$ & $-0.18 \pm 0.31(0.56)$ \\
\hline $\mathrm{PM}_{4}\left(\mu \mathrm{g} / \mathrm{m}^{3}\right)$ & $-0.08 \pm 0.51(0.88)$ & $0.17 \pm 0.19(0.37)^{*}$ & $0.29 \pm 1.12(0.79)$ & $-0.21 \pm 0.39(0.60)$ & $-0.88 \pm 0.35(0.02)$ & $0.94 \pm 0.64(0.15)$ \\
\hline $\mathrm{PM}_{10}\left(\mu \mathrm{g} / \mathrm{m}^{3}\right)$ & $0.52 \pm 0.26(0.05)$ & $0.11 \pm 0.09(0.20)^{*}$ & $\begin{array}{l}-1.46 \pm 0.44 \\
(0.01)\end{array}$ & $-0.24 \pm 0.20(0.24)$ & $-0.12 \pm 0.18(0.49)$ & $0.39 \pm 0.31(0.21)$ \\
\hline
\end{tabular}

* For each pair exposure-anion, the association was evaluated using linear regression models with the (log-transformed) daily evolution of anion (ratio post-shift/preshift) as dependent variable, the personal exposure as independent predictor variable, and BMI as adjustment variable to control for confounding/effect modification.

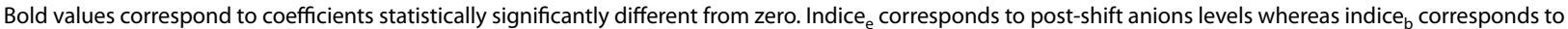
pre-shift anion levels

* BMI statistically significant

${ }^{\dagger}$ Strongly influenced by one extreme point

security guards had the highest $\mathrm{Al}$ level and $\mathrm{Cu}$ being as high as for locomotive operators. Nevertheless, when considering metals in $\mathrm{EBC}$, only $\mathrm{Cu}$ and $\mathrm{Zn}$ could be quantified. The very low Fe concentrations in this matrix suggests a strong sequestration in the lungs for this essential element [27].

In this study, we observed signs of oxidative stress in the worker's $\mathrm{EBC}$, as measured through MDA quantification, a biomarker of oxidative stress in the airways [33]. The station agents exhibited the highest MDA concentrations, suggesting the presence of oxidative stress in their airways. Interestingly, this group had also the highest PNC exposure. Our finding is in line with in vitro studies showing that transition metals enriched PM, similar to subway PM [15] or residual oil fly ash [3436], can induce oxidative stress and inflammation. Based on Fig. 2, such a perturbed redox homeostasis could be associated with elevated levels of acetate and a higher ratio $\mathrm{NO}_{2}{ }^{-} / \mathrm{NO}_{3}{ }^{-}$. On the other side, security guards presented the lowest MDA level in EBC but a statistically 
significantly higher level of lactate and $\Sigma \mathrm{NO}_{\mathrm{x}}$ compared to the two other groups. These different distributions of anions in EBC could be attributed only to their occupational activity. We did not observe a clear effect of the day on the anion concentrations in $\mathrm{EBC}$, indicative of an absence of effect due to a cumulative PM exposure during the week. This suggests a rather constant physiological activity among the different groups or the efficacy of adaptive mechanisms regulating anion homeostasis. As the occupational exposure was different for the three groups, we supposed that the anion variability during a work-shift would be associated with PM exposure, a likely source of these differences in EBC's metabolites levels. Concentrations of anions in EBC varied depending on the PM fraction and time after exposure. The PNC and LDSA at lag 0 was mainly associated with nitrogen oxides variations during the shift. The negative association between exposure to PNC and the $\Sigma \mathrm{NO}_{\mathrm{x}}$ concentrations (Table 2) corresponds to an inhibitory effect of UFP on this variable. This result is coherent with data from Rundell et colleagues [37], who also found a decreased nitrate concentration in the EBC of healthy young subjects exercising during high PNC exposure (>200,000 \#/ $\mathrm{cm}^{3}$ ). The observed decrease was attributed either to an inhibition of the nitric oxide synthase (NOS), as observed in rats exposed to diesel particles [38], or to the formation of a peroxynitrite derivative by reaction of $\mathrm{NO}$ with superoxide anion. Our additional result indicating a statistically significant association between $\mathrm{PNC}$ and the increased proportion of $\mathrm{NO}_{2}{ }^{-}$compared to $\mathrm{NO}_{3}{ }^{-}$during the work-shift (Table 2) is more in favour of the inhibition of NOS. Indeed, in order to maintain the NO homeostasis, the reductive nitrate-nitrite-NO pathway [39] could be up-regulated, explaining the decreased $\Sigma \mathrm{NO}_{\mathrm{x}}$ and the displacement of the ratio $\mathrm{NO}_{2}{ }^{-} / \mathrm{NO}_{3}{ }^{-}$in favour of the reduced nitrite form. In coherence with this hypothesis, exposure to UFP has been shown to decrease the levels of nitrate in the blood but not nitrite [40]. Short-term exposure of healthy volunteers to traffic air pollutants has also been shown to induce a transient increase of nitrite levels in EBC [41]. At lag 1, we observed that the PM mass was associated with a decreasing level of acetate, lactate and $\Sigma \mathrm{NO}_{\mathrm{x}}$ during the shift. These results suggest a build-up of these anions during the night, in response to the PM exposure of the previous day. Differences in "timing" of action between UFP and micrometer PM has already been reported [42] and attributed to their different fate when deposited in the lungs. In particular, the solubility of metallic particles in the lung lining fluid is different between fine and coarse fractions, with larger particles being less soluble [43]. This could explain the delayed response observed for lactate.

\section{Relevance of the different anions as biomarkers of effect}

The changes in the EBC's anion concentrations could be the sign of metabolic adaptation in order to face changes in the redox homeostasis resulting from the exposure to metal-rich particles. This additional cellular strategy linking metabolism and antioxidative defense to mitigate ROS and oxidative stress has been recognized only recently for bacteria [44]. We observed that lactate, acetate as well as nitrite and nitrate were the anions mostly affected by exposure to subway PM. The traditional view of lactate as a waste produced during anaerobic conditions has to be reconsidered [45]. Indeed, lactate appears to be a very important metabolite as it links the glycolysis with the aerobic pathways. It is continuously produced during aerobic glycolysis or during stressful conditions and functions as a major energy source for mitochondrial respiration in addition to be an important gluconeogenetic precursor and signaling molecule. Lactate production increases when the biological demand for energy or oxygen exceed their supply [46] and can be considered as a marker of acute lung inflammation [47]. Lactate levels in the EBC of security guards increased compared to locomotive operators and station agents (Fig. 2). In addition, significant correlations were observed between lactate and concentrations of metals or sub-micrometer particles in EBC (Table 1). Taken together, these results are suggestive of an increase in the energy demand to sustain the lung metabolism in security guards. Such energy increase could result from the presence of soluble metals in $\mathrm{EBC}$, which might trigger perturbations in the redox homeostasis. In particular, soluble $\mathrm{Cu}$ could be a potent source of $\mathrm{H}_{2} \mathrm{O}_{2}$ or of hydroxyl radical when reducing species like ascorbic acid are present in the milieu [48, 49]. Of note is the higher $\mathrm{Cu}$ level measured in $\mathrm{EBC}$ of security guards $\left(1.05 \mu \mathrm{g} / \mathrm{L}, \mathrm{CI}_{95 \%}=0.84-1.27 \mu \mathrm{g} / \mathrm{L}\right.$, Additional file 1: Table S2) compared to the two other professional groups.

Acetate, a short chain fatty acid (SCFA), is a metabolite often detected in EBC due to its high concentration (in the order of tens of micromolar). SCFAs are known to regulate inflammation by acting on leukocytes' functions and endothelial cells [50]. Our results suggest higher acetate levels for the station agents compared to the two other groups (Fig. 2). This anion is positively correlated with MDA but negatively correlated with $\mathrm{Cu}$ and Cr concentration in EBC (Table 1). It is worth mentioning that ROS can contribute to the production of acetate through the oxidative decarboxylation of pyruvate [51]. In that case, pyruvate plays the role of an antioxidant and the resulting acetate metabolite can be used in replacement in the mitochondria, allowing the constant formation of acetyl-CoA, even under hypoxia or other cellular challenges [51]. The positive but rather weak correlation 
between acetate and MDA (Table 1) could be an argument in favor of this oxidative decarboxylation of pyruvate in presence of ROS. An increase of acetate levels in $E B C$ was reported for different diseases presenting an important inflammatory component like chronic obstructive pulmonary disease $[52,53]$ or for primary ciliary dyskinesia bronchiectasis [54]. This increase of acetate was attributed to an increase of energy requirement $[53,54]$. Nevertheless, metabolomic studies in in vitro assays gave contrasted results. For example, liver [55] or HeLa cells [56] exposed to silica nanoparticles resulted in acetate reduction. Huang et al. [57] also reported a decrease of acetate in A546 cells when exposed to $\mathrm{PM}_{2.5}$.

Nitrite $\left(\mathrm{NO}_{2}{ }^{-}\right)$and nitrate $\left(\mathrm{NO}_{3}{ }^{-}\right)$should not be considered as waste products resulting from the oxidation of $\mathrm{NO}$, but rather as a storage pool for NO production, in complement to the NO-synthase (NOS) pathway. Indeed, during hypoxia, acidosis or metabolic stress, when the oxygen-dependent NOS enzyme might be compromised, $\mathrm{NO}$ can be produced by reduction of $\mathrm{NO}_{2}{ }^{-}$through involvement of haemoglobin, ascorbate or xanthine oxidoreductase among others (nitrate-nitrite-NO reductive pathway, [39]). $\mathrm{NO}_{2}{ }^{-}$appears central in controlling vasodilation in hypoxic or in metabolic stress conditions. The increased $\mathrm{NO}_{2}{ }^{-} / \mathrm{NO}_{3}{ }^{-}$ratio observed for station agents suggests that for this professional group, the oxidized form $\left(\mathrm{NO}_{3}{ }^{-}\right)$is less favored than $\mathrm{NO}_{2}{ }^{-}$. In order to explain this observation, we speculate that this increased ratio corresponds to an attempt of the lungs to compensate the locally hypoxic state induced by oxidative stress. Indeed, $\mathrm{PM}_{2.5}$ inhalation as well as UFP exposure is associated with a reduced oxygen saturation [58-60] and can induce endothelial dysfunction, particularly by inhibiting the endothelial NO synthase [61]. Such modifications might promote development of pulmonary and systemic inflammation. Magnani et al. [35] showed that mice exposed to metal-coated silica nanoparticles increase their oxygen consumption up to $70 \%$. In that case, vasodilation is necessary to supply a sufficient level of $\mathrm{O}_{2}$ for tissue or cell function. In order to maintain the physiologic NO levels needed for regulating the vascular tone, nitrate could be reduced to nitrite, which would be subsequently transformed to NO by NOS-independent pathways. This could explain the observed association between formate and nitrite (Table 1), considering formate as an electron donor for $\mathrm{NO}_{3}{ }^{-}$reduction [62]. Finally, the positive correlation between $\mathrm{MDA}$ and the ratio $\mathrm{NO}_{2}{ }^{-} / \mathrm{NO}_{3}{ }^{-}$ (Table 1) suggests that $\mathrm{NO}_{2}{ }^{-}$is increased compared to $\mathrm{NO}_{3}{ }^{-}$when oxidative stress is present.

$\Sigma \mathrm{NO}_{\mathrm{x}}$ appears a promising marker of nitrosative/oxidative stress [63]. $\Sigma \mathrm{NO}_{\mathrm{x}}$ for security guards $(4.81 \mu \mathrm{M}$, $\mathrm{CI}_{95 \%}=3.8-5.8 \mu \mathrm{M}$, Additional file 1: Table S2) is consistent with the averaged value of $5.6 \pm 5.1 \mu \mathrm{M}$, collected from other studies [26]. Compared to these values, station agents and locomotive operators present a lower level of $\Sigma \mathrm{NO}_{\mathrm{x}}$ (Additional file 1: Table S2). Saliva contains elevated levels of nitrate, possibly inducing contamination problems during EBC collection. We had to discard all samples from one security guard due to clear salivary contamination resulting in outlier values $\left(\mathrm{NO}_{3}{ }^{-}\right.$levels as high as $218 \mu \mathrm{M})$. In this study, security guards were the professional group with the largest exposure to the coarse fraction as mentioned earlier. Such an observation is coherent with results reported by Manney et al. [63], indicating that the coarse fraction of PM measured at central sites of different European cities was the strongest predictor for EBC $\Sigma \mathrm{NO}_{\mathrm{x}}$. Knowing that the coarse fraction is often originating from mechanical processes (abrasion, brake and tire wear), such a result points toward the importance of this subway PM fraction in relation to a possible adverse effect on the respiratory system.

Exposure to micro or nano-sized $\mathrm{ZnO}$ particles $[64,65]$ or welding fumes containing zinc and/or copper [66] has been shown to induce an acute phase response through the increase of serum amyloid A and C-reactive proteins in blood of healthy exposed volunteers. Elevation of these two proteins in blood is associated with an increased risk of cardiovascular diseases. By analogy to these reports, and considering the presence of $\mathrm{Cu}$ and $\mathrm{Zn}$ in $\mathrm{EBC}$ as well as the modified pattern of anions (mainly $\Sigma \mathrm{NO}_{\mathrm{x}}$ ) in our subway workers, adverse cardiovascular effects might be expected in this population. Whereas we did not sample blood in our study due to its invasive nature, blood should be considered in further research regarding possible effects of subway PM exposure on cardiovascular system.

\section{Strengths and limitations}

One of the main strengths of this study is that the individual exposure to different PM fractions has been thoroughly characterised with a simultaneous collection of EBC over the two-week period. This allowed us to look precisely to the relationships between exposure and metabolite levels. In addition, we used validated methods for the analysis of these different metabolites [69, 70]. This is a prerequisite for proposing $\mathrm{EBC}$ as a relevant matrix for future clinical studies [67]. Finally, an approach combining multiple biomarkers in $\mathrm{EBC}$ is mandatory, as multiple and intricated metabolic pathways are often influenced by exposure to different environmental stressors [6]. For example, the metabolomics approach usually outperforms the discrimination between asthmatic and non-asthmatics compared to conventional clinical tests using either exhaled NO or standard spirometry [68]. 
The additional interest to focus on a pattern of different metabolites in EBC relates to the fact that it gives insight into the actual functional status of the lungs and comparison with basal levels could indicate atypical physiological status [6].

Nevertheless, the selected anions in this study were related only to nitrosative stress and glycolysis, narrowing the number of considered pathways when compared to more sophisticated metabolomics techniques. It is the reason why such comprehensive techniques should be involved in complement to the more specific and focussed approach we used in this pilot study. The issue of a low number of participants included was partially resolved by the longitudinal design of the study with a continuous personal exposure measure over the work-shift and twice a day measures of the outcomes for each participant. Indeed, we expected a decreased inter-individual variability, improving by this way the possibility to observe modifications of the metabolites levels in EBC. However, we acknowledge that all comparisons of job groups, even when statistically significant, lack robustness. Moreover, a gender effect might be present as the station agents group consisted only of women, in contrary to both other groups. That is why the results pertaining to the comparison of job groups have to be considered with caution and will need further confirmation. For that purpose, an epidemiological study including about 300 volunteers belonging to these three professional groups is in progress in the same company, with the intended aim to demonstrate the usefulness of the different selected anions from this pilot study [29]. A final issue is the multiplicity of comparisons. We did not provide Bonferroni-type adjusted p-values given that such adjustments rely on the number of tests made which can be easily manipulated. We prefer to consider our results as exploratory and a statistical significant result as a flag for the reader of a possible real effect.

\section{Conclusion}

In this pilot study, we found that three different professional groups exposed to subway particulate levels and occupational conditions presented specific patterns of anions in their EBC. Nitrogen oxides (nitrite/ nitrate ratio and $\Sigma \mathrm{NO}_{\mathrm{x}}$ ) as well as acetate and lactate appeared the most modified metabolites after exposure to subway PM. We also observed that these changes are modulated by the PM size, with UFP and coarse particles inducing different responses. Such changes are suggestive of cellular strategies to maintain the redox and metabolic balance when under oxidative stress.
The combined measurement of these anions in EBC could be helpful to investigate the cardiopulmonary effects resulting from exposure to subway PM on workers and the general population.

\section{Material and methods \\ Study design and participants}

This longitudinal pilot-study belongs to the broader Respiratory disease Occupational Biomonitoring Collaborative Project (ROBoCoP project), which research protocol has been described elsewhere [29]. The aims of this pilot study were to: 1 . understand the suitability of different candidate biomarkers for biomonitoring of workers exposed to metallic PM; 2 . to select the most relevant biomarkers for COPD or asthma detection in a larger epidemiological study of subway workers. Volunteers were recruited based on their workplace attribution to the subway line 7 . This line is completely underground with PM concentrations corresponding to the worst case scenario. Three different professional groups were recruited, each composed of three healthy nonsmokers: station agents (women only); locomotive operators and security guards (both composed of men only). A detailed description of their activities is available in [27]. We measured exposure parameters and collected biological matrices by job type during two consecutive weeks for each group.

\section{Exposure to particulate matter and analysis}

Worker's personal exposure to different PM fractions (UFP, $\mathrm{PM}_{2.5}, \mathrm{PM}_{4}, \mathrm{PM}_{10}$ ) and total metal concentration was determined for all nine volunteers during two consecutive weeks (excluding the weekend) [27]. Briefly, active personal sampling for PM was achieved using Teflon filters connected to a pump with flow set at 4 or 10 $\mathrm{L} / \mathrm{min}$, depending on the collected fraction. After standard gravimetric analysis of the filters, they were digested in acids and the resulting solution analyzed by inductive coupled plasma mass spectrometry (ICP-MS; ICap TQ, Thermo Scientific, Switzerland) for 11 elements (Al, As, $\mathrm{Ba}, \mathrm{Cd}, \mathrm{Cr}, \mathrm{Cu}, \mathrm{Fe}, \mathrm{Mn}, \mathrm{Ni}, \mathrm{Pb}$ and $\mathrm{Zn}$ ). A direct-reading particle counter instrument (DiscMini, Testo, Switzerland) was used for personal UFP measurement.

\section{EBC collection and analysis}

Pre- and post-shift EBC samples were collected on a daily basis using a portable collection device (Turbo-DECCS, Medivac, Parma, Italy) set at $-10{ }^{\circ} \mathrm{C}$. Sampling took place in a clean room, located either at the subway station Porte de la Villette or at Gare de Lyon and following the recommendations of the American Thoracic Society and the European Respiratory Society Task Force [23]. None of participants declared drinking tea or coffee an 
hour before EBC collection. A total volume of $2-3 \mathrm{~mL}$ of EBC per participant was collected during the $20 \mathrm{~min}$ sampling. Immediately after collection, EBC sample was aliquoted in the same room. For anion analysis, $100 \mu \mathrm{l}$ of the collected EBC was transferred into conical plastic vials (300 $\mu \mathrm{l}$, Macherey Nagel, Düren, Germany) whereas $250 \mu \mathrm{l}$ of EBC was aliquoted in vials $(1.5 \mathrm{ml}$, Macherey Nagel, Düren, Germany) for MDA analysis. Aliquots were frozen at $-80^{\circ} \mathrm{C}$ until analysis.

Anions associated to nitrosative stress $\left(\mathrm{NO}_{2}{ }^{-}\right.$and $\mathrm{NO}_{3}{ }^{-}$as stable end-product of $\mathrm{NO}$ oxidation) or to metabolism (lactate, acetate, propionate, butyrate, formate and pyruvate) were analyzed in EBC following a validated method [26]. Briefly, $10 \mu \mathrm{l}$ of the EBC sample was injected without any treatment into a Dionex ICS $5000+$ ion chromatograph, equipped with an analytical column IonPac AS11-HC250 mm, $4 \mu \mathrm{m}$ (ThermoFisher Scientific, Ecublens, Switzerland) and a conductivity detector. The low LOD, comprised between 0.07 and $0.58 \mu \mathrm{M}$ (depending on the analyte) allowed the quantification of all these anions in all samples.

MDA is a stable end-product of lipid peroxidation and is considered as a marker of oxidative stress [33]. This molecule was measured in the EBC sample using dinitrophenyl hydrazine (DNPH) as derivatisation agent. Briefly, the validated method [69] consisted in adding $50 \mu \mathrm{l}$ of a $2 \mathrm{mM}$ DNPH solution to $125 \mu \mathrm{l}$ of EBC sample, containing MDA- $\mathrm{d}_{2}$ as internal standard. The reaction mixture was heated to $50{ }^{\circ} \mathrm{C}$ during $2 \mathrm{~h}$, cooled to ambient temperature than directly injected into a LC-MS/MS instrument. About 19\% of the samples had MDA concentrations below the LOD of $70 \mathrm{pg} / \mathrm{ml}$.

Copper $(\mathrm{Cu})$, manganese $(\mathrm{Mn})$, nickel $(\mathrm{Ni})$, chrome $(\mathrm{Cr})$ and zinc $(\mathrm{Zn})$ as well as the number concentration of sub-micrometer particles in the EBC samples were determined by ICP-MS technique (metals) and nanoparticle tracking analysis (NTA) respectively. Details for theses analytical methods can be found in [27] and [70], respectively. The observed LOD was $0.003 \mu \mathrm{g} / \mathrm{L}$ for $\mathrm{Cr}, \mathrm{Ni}$ and $\mathrm{Mn}, 0.07 \mu \mathrm{g} / \mathrm{L}$ for $\mathrm{Cu}$ and $0.3 \mu \mathrm{g} / \mathrm{L}$ for $\mathrm{Zn}$ and Fe. The LOD for the NTA was $2.7 \times 10^{7}$ particles $/ \mathrm{ml}$.

\section{Data management and statistical analysis}

One of the security guards had a high salivary production during the EBC collection, which contaminated some of his samples. This resulted in a very high $\mathrm{NO}_{3}{ }^{-}$concentration in these EBC samples. We considered this worker as an outlier and therefore these samples were excluded from the statistical analyses reported in this paper.

Individuals' anion concentrations, nitrite/nitrate ratio as well as the sum of nitrite and nitrate $\left(\Sigma \mathrm{NO}_{\mathrm{x}}\right)$ were first log-transformed. In a second step, these variables were analyzed using linear mixed effects models with the subject ID as a random effect. For each of these outcomes, we fitted a model including the job group, the day of the week (in order to detect a possible cumulative effect over the week) and the shift (pre- vs. post-shift). All pairwise interactions were tested between these three factors. We further adjusted on the body mass index (BMI) in order to account for a possible effect of this factor on the metabolism. In a third step, pairwise Pearson correlation coefficients were computed for the variable measured in EBC samples (anions, MDA, metals, sub-micrometer particles). Given that these substances were all measured within the same EBC samples, these correlations coefficients did not take into account any other variable. This enabled, on the one hand, to assess the presumed associations related to nitrosative/oxidative stress or metabolism, and, on the other hand, to highlight potential associations between exposure biomarkers (metals, sub-micrometer particles) and effect biomarkers (MDA, anions).

Lastly, the within-day evolution of EBC anion concentrations was characterized for each anion as the ratio of the post-shift and the pre-shift concentrations. These (log-transformed) ratios were then analyzed using a linear mixed effect model with the participant ID as a random effect variable. Independent variables were the external exposure measurements conducted in the workplace $\left(\mathrm{PM}_{10}, \mathrm{PM}_{2.5}\right.$, airborne metal concentration and $\mathrm{PNC}$ ) obtained during either the same (lag 0 ) or previous (lag 1) EBC collection day. For lag 1, the first day of the working week was excluded. Standard checks for heteroskedasticity and outliers were performed. These led to the exclusion of the subject mentioned at the beginning of the paragraph.

\section{Abbreviations \\ $\mathrm{Cl}_{95 \%}$ : 95\% Confidence interval; Cr: Chromium; Cu: Copper; EBC: Exhaled breath condensate; Fe: Iron; $\mathrm{H}_{2} \mathrm{O}_{2}$ : Hydrogen peroxide; ICP-MS: Inductively coupled plasma mass spectrometry; LDSA: Lung deposited surface area; LOD: Limit of detection; LOQ: Limit of quantification; MDA: Malondialdehyde; Mn: Manganese; Ni: Nickel; $\mathrm{NO}$ : Nitric oxide; $\mathrm{NO}_{2}{ }^{-} / \mathrm{NO}_{3}{ }^{-}$: Ratio of nitrite to nitrate; NOS: Nitric oxide synthase; $\Sigma N O_{x}$ : Sum of nitrite and nitrate; NTA: Nanoparticle tracking analysis; PM: Particulate matter; PNC: Particle number concentration; RoBoCoP: Respiratory disease occupational biomonitoring collaborative pro- ject; ROS: Reactive oxygen species; SCFA: Short chain fatty acids; UFP: Ultrafine particles; Zn: Zinc.}

\section{Supplementary Information}

The online version contains supplementary material available at https://doi. org/10.1186/s12989-022-00456-z.

Additional file 1: Supplemental Table S1. Average exposure level of the three different professional groups. Supplemental Table S2. Geomtric concentration of the selected variables in EBC samples collected during the two working weeks for the three professional categories. Supplemental Figure S1. Effect of the professional activity on the predicted EBC levels of MDA. Supplemental Table S3. Averaged EBC concentration of selected anions in pre- and post-shift for all volunteers. 


\section{Acknowledgements}

The authors would like to thank all the volunteers who agreed to participate to this study, the company staff who helped with study planning and data collection, particularly G. Carillo, S. Besançon, T. Ben Rayana and the technicians of the Régie Autonome des Transports Parisiens (RATP) who helped with the exposure assessment. We greatly appreciate the chemical analyses performed by the University Center of Legal Medicine, Lausanne - Geneva (anions and metals).

\section{Authors' contributions}

IGC, NBH, PW, JJS, GS, VJ, AD and JAP conceived the study. IGC, GS, JJS, MH, VJ, $A D$ and JAP organised the field campaign and $M H, V J$ and $A D$ realised it. $M H$ did the MDA analysis and JJS the NTA measurements. Data curation and data base management was done by CC, IGC and PW. The formal statistical analysis was done by PW. The funding acquisition and the project administration was done by IGC. The original draft was written by JJS and reviewed by all the coauthors. All authors read and approved the final manuscript.

\section{Funding}

Schweitzerische Nationalfonds zur Förderung der Wissenschaftlischen Forschug (Grant No. IZCOZO-177067).

\section{Availability of data and materials}

The datasets used and/or analyzed for the current study are available from the corresponding author on reasonable request.

\section{Declarations}

\section{Ethics approval and consent to participate}

This study follows the guidelines of the Helsinki Declaration; all subjects were fully informed by medical doctors about the study's aims and gave their free and informed consent prior to inclusion. The study was approved by the Comité de protection des personnes, Ile de France, France (reference 2019A01652 55)

\section{Consent for publication}

All authors have given approval to the final version of the manuscript.

\section{Competing interests}

The authors declare no conflict of interest.

\section{Author details}

'Department of Occupational and Environmental Health, Center for Primary Care and Public Health (Unisanté), University Lausanne, Route de la Corniche 2, 1066 Epalinges, Switzerland. '2Service Santé-Travail, Autonomous Paris Transport Authority (RATP), 88 Boulevard Sébastopol, 75003 Paris, France. ${ }^{3}$ Division of Pulmonary Diseases, Geneva University Hospitals and Faculty of Medicine, University of Geneva, Rue Gabrielle Perret-Gentil 4, 1205 Geneva, Switzerland. ${ }^{4}$ Division of Research Management, National Research and Safety Institute (INRS), Rue du Morvan, CS 60027, 54519 Vandoeuvre Cedex, France.

\section{Received: 14 December 2021 Accepted: 14 February 2022} Published: 25 February 2022

\section{References}

1. Brook RD, Rajagopalan S, Pope CA, Brook JR, Bhatnagar A, Diez-Roux $\mathrm{AV}$, et al. Particulate matter air pollution and cardiovascular disease an update to the scientific statement from the American Heart Association. Circulation. 2010;121(21):2331-78. https://doi.org/10.1161/CIR.0b013 e3181dbece1.

2. Rao XQ, Zhong JX, Brook RD, Rajagopalan S. Effect of particulate matter air pollution on cardiovascular oxidative stress pathways. Antioxid Redox Signal. 2018;28(9):797-818. https://doi.org/10.1089/ars.2017.7394.

3. Royal College of Physicians (RCPCH). Every breath we take: the lifelong impact of air pollution. In: Report of a working party 2016. 11 St Andrews Place, Regent's Park, London NW1 4LE, https://www.rcplondon.ac.uk/file/ 2916/download, Accessed the 7.6.2021.
4. Li N, Sioutas C, Cho A, Schmitz D, Misra C, Sempf J, et al. Ultrafine particulate pollutants induce oxidative stress and mitochondrial damage. Environ Health Perspect. 2003;111(4):455-60. https://doi.org/10.1289/ ehp.6000.

5. Daiber A, Kuntic M, Hahad O, Delogu LG, Rohrbach S, Di Lisa F, et al. Effects of air pollution particles (ultrafine and fine particulate matter) on mitochondrial function and oxidative stress: implications for cardiovascular and neurodegenerative diseases. Arch Biochem Biophys. 2020;696:108662. https://doi.org/10.1016/j.abb.2020.108662.

6. Kelly FJ, Fussell JC. Metabolomics as a tool to unravel the oxidative stressinduced toxicity of ambient air pollutants. 2020.

7. Song YY, Li RJ, Zhang YH, Wei JT, Chen W, Chung CKA, et al. Mass spectrometry-based metabolomics reveals the mechanism of ambient fine particulate matter and its components on energy metabolic reprogramming in BEAS-2B cells. Sci Total Environ. 2019;651:3139-50. https:// doi.org/10.1016/j.scitotenv.2018.10.171.

8. Huang QY, Zhang J, Luo LZ, Wang XF, Wang XX, Alamdar A, et al. Metabolomics reveals disturbed metabolic pathways in human lung epithelial cells exposed to airborne fine particulate matter. Toxicol Res. 2015:4(4):939-47. https://doi.org/10.1039/c5t×00003c.

9. Walker DI, Lane KJ, Liu K, Uppal K, Patton AP, Durant JL, et al. Metabolomic assessment of exposure to near-highway ultrafine particles. J Expo Sci Environ Epidemiol. 2019;29(4):469-83. https://doi.org/10.1038/ s41370-018-0102-5

10. Reyes-Caballero H, Rao XQ, Sun QS, Warmoes MO, Penghui L, Sussan TE, et al. Air pollution-derived particulate matter dysregulates hepatic Krebs cycle, glucose and lipid metabolism in mice. Sci Rep. 2019. https://doi. org/10.1038/s41598-019-53716-y.

11. Yang BY, Fan SJ, Thiering E, Seissler J, Nowak D, Dong GH, et al. Ambient air pollution and diabetes: A systematic review and meta-analysis. Environ Res. 2020;180:108817. https://doi.org/10.1016/j.envres.2019.108817.

12. Paris $D$, Maniscalco $M$, Motta A. Nuclear magnetic resonance-based metabolomics in respiratory medicine. Eur Respir J. 2018;52(4):1801107. https://doi.org/10.1183/13993003.01107-2018.

13. Marchini T, Zirlik A, Wolf D. Pathogenic role of air pollution particulate matter in cardiometabolic disease: evidence from mice and humans. Antioxid Redox Signal. 2020;33(4):263-79. https://doi.org/10.1089/ars 2020.8096.

14. Oberdorster G, Oberdorster E, Oberdorster J. Nanotoxicology: An emerging discipline evolving from studies of ultrafine particles. Environ Health Perspect. 2005;113(7):823-39. https://doi.org/10.1289/ehp.7339.

15. Loxham M, Nieuwenhuijsen MJ. Health effects of particulate matter air pollution in underground railway systems: a critical review of the evidence. Part Fibre Toxicol. 2019. https://doi.org/10.1186/ s12989-019-0296-2

16. Van Ryswyk K, Anastasopolos AT, Evans G, Sun L, Sabaliauskas K, Kula R, et al. Metro commuter exposures to particulate air pollution and PM2.5 Associated elements in three Canadian cities: the urban transportation exposure study. Environ Sci Technol. 2017;51(10):5713-20. https://doi. org/10.1021/acs.est.6b05775.

17. Borghi F, Fanti G, Cattaneo A, Campagnolo D, Rovelli S, Keller M, et al. Estimation of the inhaled dose of airborne pollutants during commuting: case study and application for the general population. Int J Environ Res Public Health. 2020;17(17):6066. https://doi.org/10.3390/ijerph17176066.

18. Moreno T, Kelly FJ, Dunster C, Oliete A, Martins V, Reche C, et al. Oxidative potential of subway PM2.5. Atmos Environ. 2017;148:230-8. https://doi. org/10.1016/j.atmosenv.2016.10.045.

19. Gali NK, Jiang SY, Yang FH, Sun L, Ning Z. Redox characteristics of sizesegregated PM from different public transport microenvironments in Hong Kong. Air Qual Atmos Health. 2017;10(7):833-44. https://doi.org/10. 1007/s11869-017-0473-0.

20. Karlsson HL, Nilsson L, Moller L. Subway particles are more genotoxic than street particles and induce oxidative stress in cultured human lung cells. Chem Res Toxicol. 2005;18(1):19-23. https://doi.org/10.1021/tx049 $723 c$.

21. Cooper DM, Loxham M. Particulate matter and the airway epithelium: the special case of the underground? Eur Respir Rev. 2019;28(153):190066. https://doi.org/10.1183/16000617.0066-2019.

22. Karlsson HL, Holgersson A, Moller L. Mechanisms related to the genotoxicity of particles in the subway and from other sources. Chem Res Toxicol. 2008;21(3):726-31. https://doi.org/10.1021/tx7003568. 
23. Horvath I, Hunt J, Barnes PJ. Exhaled breath condensate: methodological recommendations and unresolved questions. Eur Respir J. 2005:26(3):523-48.

24. Shoman Y, Wild P, Hemmendinger M, Graille M, Sauvain JJ, Hopf NB, et al. Reference ranges of 8-isoprostane concentrations in exhaled breath condensate (EBC): a systematic review and meta-analysis. Int J Mol Sci. 2020:21(11):3822. https://doi.org/10.3390/ijms21113822.

25. Maniscalco M, Fuschillo S, Paris D, Cutignano A, Sanduzzi A, Motta A. Clinical metabolomics of exhaled breath condensate in chronic respiratory diseases. Adv Clin Chem. 2019;88:121-49. https://doi.org/10.1016/bs.acc. 2018.10.002.

26. Sauvain JJ, Edme JL, Wild P, Suarez G, Bezerra O, Talvani A, et al. Does exposure to inflammatory particles modify the pattern of anion in exhaled breath condensate? J Breath Res. 2020;14(2):026005. https://doi. org/10.1088/1752-7163/ab5d88.

27. Guseva Canu I, Creze C, Hemmendinger M, Ben-Rayana T, Besancon S, Jouannique $V$, et al. Particle and metal exposure in Parisian subway: Relationship between exposure biomarkers in air, exhaled breath condensate, and urine. Int J Hyg Environ Health. 2021;237:113837. https://doi.org/10. 1016/j.ijheh.2021.113837.

28. Petremand R, Wild P, Creze C, Suarez G, Besancon S, Jouannique V, et al. Application of the Bayesian spline method to analyze real-time measurements of ultrafine particle concentration in the Parisian subway. Environ Int. 2021;156:106773. https://doi.org/10.1016/j.envint.2021.106773.

29. Canu IG, Hemmendinger M, Sauvain JJ, Suarez G, Hopf NB, Pralong JA, et al. Respiratory disease occupational biomonitoring collaborative project (ROBOCoP): a longitudinal pilot study and implementation research in the Parisian transport company. J Occup Med Toxicol. 2021. https://doi. org/10.1186/s12995-021-00312-4.

30. Louis P, Hold GL, Flint HJ. The gut microbiota, bacterial metabolites and colorectal cancer. Nat Rev Microbiol. 2014;12(10):661-72. https://doi.org/ 10.1038/nrmicro3344

31. Lee JS, Choi YC, Shin JH, Lee JH, Lee Y, Park SY, et al. Health surveillance study of workers who manufacture multi-walled carbon nanotubes. Nanotoxicology. 2015;9(6):802-11. https://doi.org/10.3109/17435390. 2014.978404

32. ANSES: Pollution chimique de l'air des enceintes de transports ferroviaires souterrains et risques sanitaires associés chez les travailleurs. In: Rapport d'expertise collective. Edited by ANSES, 2015: 382.

33. Gong J, Zhu T, Kipen H, Wang G, Hu M, Ohman-Strickland P, et al. Malondialdehyde in exhaled breath condensate and urine as a biomarker of air pollution induced oxidative stress. J Expo Sci Environ Epidemiol. 2013;23(3):322-7. https://doi.org/10.1038/jes.2012.127.

34. Caceres L, Paz ML, Garces M, Calabro V, Magnani ND, Martinefski M, et al. $\mathrm{NADPH}$ oxidase and mitochondria are relevant sources of superoxide anion in the oxinflammatory response of macrophages exposed to airborne particulate matter. Ecotoxicol Environ Saf. 2020:205:111186. https://doi.org/10.1016/j.ecoenv.2020.111186.

35. Magnani ND, Marchini T, Garces M, Mebert A, Caceres L, Diaz L, et al. Role of transition metals present in air particulate matter on lung oxygen metabolism. Int J Biochem Cell Biol. 2016;81:419-26. https://doi.org/10. 1016/j.biocel.2016.10.009.

36. Marchini T, Magnani ND, Paz ML, Vanasco V, Tasat D, Maglio DHG, et al. Time course of systemic oxidative stress and inflammatory response induced by an acute exposure to Residual Oil Fly Ash. Toxicol Appl Pharmacol. 2014;274(2):274-82. https://doi.org/10.1016/j.taap.2013.11.013.

37. Rundell KW, Slee JB, Caviston R, Hollenbach AM. Decreased lung function after inhalation of ultrafine and fine particulate matter during exercise is related to decreased total nitrate in exhaled breath condensate. Inhal Toxicol. 2008;20(1):1-9.

38. Lei YC, Hwang JS, Chan CC, Lee CT, Cheng TJ. Enhanced oxidative stress and endothelial dysfunction in streptozotocin-diabetic rats exposed to fine particles. Environ Res. 2005;99(3):335-43. https://doi.org/10.1016/j. envres.2005.03.011.

39. Lundberg JO, Weitzberg E, Gladwin MT. The nitrate-nitrite-nitric oxide pathway in physiology and therapeutics. Nat Rev Drug Discov. 2008;7(2):156-67. https://doi.org/10.1038/nrd2466.

40. Shah AP, Pietropaoli AA, Frasier LM, Speers DM, Chalupa DC, Delehanty JM, et al. Effect of inhaled carbon ultrafine particles on reactive hyperemia in healthy human subjects. Environ Health Perspect. 2008;116(3):375-80. https://doi.org/10.1289/ehp.10323.
41. Laumbach RJ, Kipen HM, Ko S, Kelly-McNeil K, Cepeda C, Pettit A, et al. A controlled trial of acute effects of human exposure to traffic particles on pulmonary oxidative stress and heart rate variability. Part Fibre Toxicol. 2014. https://doi.org/10.1186/s12989-014-0045-5.

42. Gong J, Zhu T, Kipen H, Wang G, Hu M, Guo Q, et al. Comparisons of ultrafine and fine particles in their associations with biomarkers reflecting physiological pathways. Environ Sci Technol. 2014;48(9):5264-73. https:// doi.org/10.1021/es5006016.

43. Jiang SY, Kaul DS, Yang FH, Sun L, Ning Z. Source apportionment and water solubility of metals in size segregated particles in urban environments. Sci Total Environ. 2015;533:347-55. https://doi.org/10.1016/j.scito tenv.2015.06.146.

44. Lemire J, Alhasawi A, Appanna VP, Tharmalingam S, Appanna VD. Metabolic defence against oxidative stress: the road less travelled so far. J Appl Microbiol. 2017;123(4):798-809. https://doi.org/10.1111/jam.13509.

45. Brooks GA. Lactate as a fulcrum of metabolism. Redox Biol. 2020;35:101454. https://doi.org/10.1016/j.redox.2020.101454

46. Rabinowitz JD, Enerback S. Lactate: the ugly duckling of energy metabolism. Nat Metab. 2020;2(7):566-71. https://doi.org/10.1038/ s42255-020-0243-4.

47. Wolak JE, Esther CR, O'Connell TM. Metabolomic analysis of bronchoalveolar lavage fluid from cystic fibrosis patients. Biomarkers. 2009;14(1):5560. https://doi.org/10.1080/13547500802688194.

48. Shen $\mathrm{H}$, Anastasio C. A comparison of hydroxyl radical and hydrogen peroxide generation in ambient particle extracts and laboratory metal solutions. Atmos Environ. 2012;46:665-8. https://doi.org/10.1016/j.atmos env.2011.10.006.

49. Charrier JG, Anastasio C. Impacts of antioxidants on hydroxyl radical production from individual and mixed transition metals in a surrogate lung fluid. Atmos Environ. 2011;45(40):7555-62. https://doi.org/10.1016/j. atmosenv.2010.12.021.

50. Vinolo MAR, Rodrigues HG, Nachbar RT, Curi R. Regulation of inflammation by short chain fatty acids. Nutrients. 2011;3(10):858-76. https://doi. org/10.3390/nu3100858.

51. Bose S, Ramesh V, Locasale JW. Acetate metabolism in physiology, cancer, and beyond. Trends Cell Biol. 2019;29(9):695-703. https://doi.org/10. 1016/j.tcb.2019.05.005.

52. Bertini I, Luchinat C, Miniati M, Monti S, Tenori L. Phenotyping COPD by H-1 NMR metabolomics of exhaled breath condensate. Metabolomics. 2014;10(2):302-11. https://doi.org/10.1007/s11306-013-0572-3.

53. de Laurentiis G, Paris D, Melck D, Montuschi P, Maniscalco M, Bianco A, et al. Separating smoking-related diseases using NMR-based metabolomics of exhaled breath condensate. J Proteome Res. 2013;12(3):150211. https://doi.org/10.1021/pr301171p.

54. Paris D, Palomba L, Mirra V, Borrelli M, Corcione A, Santamaria F, et al. NMR profiling of exhaled breath condensate defines different metabolic phenotypes of non-cystic fibrosis bronchiectasis. Int J Mol Sci. 2020;21(22):8600. https://doi.org/10.3390/ijms21228600.

55. Chatterjee N, Jeong J, Yoon D, Kim S, Choi J. Global metabolomics approach in in vitro and in vivo models reveals hepatic glutathione depletion induced by amorphous silica nanoparticles. Chem-Biol Interact. 2018;293:100-6. https://doi.org/10.1016/j.cbi.2018.07.013.

56. Feng JH, Li JQ, Wu HF, Chen Z. Metabolic responses of HeLa cells to silica nanoparticles by NMR-based metabolomic analyses. Metabolomics. 2013;9(4):874-86. https://doi.org/10.1007/s11306-013-0499-8.

57. Huang DC, Zou YJ, Abbas A, Dai BN. Nuclear magnetic resonance-based metabolomic investigation reveals metabolic perturbations in PM25treated A549 cells. Environ Sci Pollut Res. 2018;25(31):31656-65. https:// doi.org/10.1007/s11356-018-3111-y.

58. Tanwar V, Katapadi A, Adelstein JM, Grimmer JA, Wold LE. Cardiac pathophysiology in response to environmental stress: a current review. Curr Opin Physio. 2018;1:198-205. https://doi.org/10.1016/j.cophys.2017.11. 005.

59. Xia X, Qiu H, Kwok T, Ko FWS, Man CL, Ho KF. Time course of blood oxygen saturation responding to short-term fine particulate matter among elderly healthy subjects and patients with chronic obstructive pulmonary disease. Sci Total Environ. 2020;723:138022. https://doi.org/10.1016/j.scito tenv.2020.138022

60. Gong H, Linn WS, Clark KW, Anderson KR, Sioutas C, Alexis NE, et al. Exposures of healthy and asthmatic volunteers to concentrated ambient 
ultrafine particles in los angeles. Inhal Toxicol. 2008;20(6):533-45. https:// doi.org/10.1080/08958370801911340.

61. Xie W, You J, Zhi CX, Li L. The toxicity of ambient fine particulate matter (PM2.5) to vascular endothelial cells. J Appl Toxicol. 2021;41(5):713-23. https://doi.org/10.1002/jat.4138.

62. Thomas SC, Alhasawi A, Auger C, Omri A, Appanna VD. The role of formate in combatting oxidative stress. Antonie Van Leeuwenhoek Int J Gen Mol Microbiol. 2016;109(2):263-71. https://doi.org/10.1007/ s10482-015-0629-6.

63. Manney S, Meddings CM, Harrison RM, Mansur AH, Karakatsani A, Analitis A, et al. Association between exhaled breath condensate nitrate plus nitrite levels with ambient coarse particle exposure in subjects with airways disease. Occup Environ Med. 2012;69(9):663-9. https://doi.org/ 10.1136/oemed-2011-100255.

64. Monse C, Raulf M, Jettkant B, van Kampen V, Kendzia B, Schurmeyer L, et al. Health effects after inhalation of micro- and nano-sized zinc oxide particles in human volunteers. Arch Toxicol. 2021;95(1):53-65. https://doi. org/10.1007/s00204-020-02923-y.

65. Monse C, Hagemeyer O, Raulf M, Jettkant B, van Kampen V, Kendzia B, et al. Concentration-dependent systemic response after inhalation of nano-sized zinc oxide particles in human volunteers. Part Fibre Toxicol. 2018. https://doi.org/10.1186/s12989-018-0246-4.

66. Baumann R, Gube M, Markert A, Davatgarbenam S, Kossack V, Gerhards $B$, et al. Systemic serum amyloid $A$ as a biomarker for exposure to zinc and/or copper-containing metal fumes. J Expo Sci Environ Epidemiol. 2018;28(1):84-91. https://doi.org/10.1038/jes.2016.86.

67. Horvath I, Barnes PJ, Loukides S, Sterk PJ, Högman M, Olin AC, et al. A European Respiratory Society technical standard: exhaled biomarkers in lung disease. Eur Respir J. 2017;49:1600965.

68. Chang-Chien J, Huang HY, Tsai HJ, Lo CJ, Lin WC, Tseng YL, et al. Metabolomic differences of exhaled breath condensate among children with and without asthma. Pediatr Allergy Immunol. 2021;32(2):264-72. https:// doi.org/10.1111/pai.13368.

69. Hemmendinger M, Sauvain JJ, Hopf N, Wild P, Suarez G, Canu IG. Method validation and characterization of the Associated uncertainty for malondialdehyde quantification in exhaled breath condensate. Antioxidants. 2021;10(11):1661. https://doi.org/10.3390/antiox10111661.

70. Sauvain JJ, Suarez G, Edme JL, Bezerra O, Silveira KG, Amaral LS, et al. Method validation of nanoparticle tracking analysis to measure pulmonary nanoparticle content: the size distribution in exhaled breath condensate depends on occupational exposure. J Breath Res. 2017;11(1):016010. https://doi.org/10.1088/1752-7163/aa56dd.

\section{Publisher's Note}

Springer Nature remains neutral with regard to jurisdictional claims in published maps and institutional affiliations.

Ready to submit your research? Choose BMC and benefit from:

- fast, convenient online submission

- thorough peer review by experienced researchers in your field

- rapid publication on acceptance

- support for research data, including large and complex data types

- gold Open Access which fosters wider collaboration and increased citations

- maximum visibility for your research: over $100 \mathrm{M}$ website views per year

At BMC, research is always in progress.

Learn more biomedcentral.com/submissions 